The $5^{\text {th }}$ International Conference on Family Business and Entrepreneurship

\title{
COMPETITIVE INTENSITY VALUE RESONANCE ANTECEDENCE FOR SUCCESSFULL BRAND PERFORMANCE
}

\author{
Imroatul Khasanah ${ }^{{ }^{*}}$, I Made Sukresna ${ }^{2}$ \\ ${ }^{1,2}$ Faculty of Economics and Business, Universitas Diponegoro \\ Corresponding author: imroatulkhasanah99@gmail.com
}

\begin{abstract}
This study aims to mediate the influence of the Brand Management System on Brand Performance by proposing a Competitive Intensity Value Resonance that mediates between the Brand Management System and the improvement of Brand Performance. Sample data from 160 food product SMEs in Central Java were used to test a model consisting of five hypotheses. The statistical test in this model uses five variables: Brand Management System, Marketing Orientation, Internal Branding, Competitive Intensity Value Resonance and Brand Performance. The results of the data show that Competitive Intensity Value Resonance has an important role in improving Brand Performance.
\end{abstract}

Keywords: Brand Management System, Market Orientation, Internal Branding, Competitive Intensity Value Resonance, Brand Performance.

\section{Introduction}

Food product SMEs are one of the leading products in Central Java. One of the problems food product SMEs in Central Java is how to improve brand performance. In the food product SMEs business environment is characterized by rapid change, affecting food product SMEs to meet consumer needs and various competitions, especially related to brand performance. Food product SMEs must always survive in every competition. Food product SMEs measure brand performance based on benchmarks such as customer loyalty to the brand/product, customer desire to repurchase and recommend products based on their positive experiences with others. The best brand management practice that can be carried out by food product SMEs is how to conduct internal company discussions where the company applies brand evaluation procedures. Market-oriented food product SMEs can lead to the development of various competitive strategies, which ultimately lead to competitive advantage and improved business performance. Internal Branding that can be done in SMEs for food products by targeting employees must focus on increasing capability and attitude performance to increase employee and customer interactions so as to create strong brand equity.

Brand Performance as a measure that refers to the success of a brand in the market which is measured in terms of brand image, brand awareness, customer brand loyalty and brand reputation. Brand awareness refers to the possibility that the brand name will appear in the minds of customers (Muhonen, Hirvonen, \& Laukkanen, 2017). The participation of frontline employees in the success of Brand Performance is also associated with helping carry out brand building activities by understanding both the goals and characteristics of the brand, the actions taken by the company and helping to improve the brand image (Iyer, Davari, Zolfagharian, \& Paswan, 2020). Brand Performance reflects the strategic achievements of the brand and its success in the marketplace. The ability of a company's brand management in this sense is very important in achieving performance because it describes the ability to communicate important aspects to target customers (W. J. T. Lee, O'Cass, \& Sok, 2019).

The purpose of Brand Performance is how brands can become profitable businesses, where measuring brand profits can be measured by measuring the performance of a brand(Luxton, Reid, \& Mavondo, 2017). By definition Brand Performance is a series of comparisons between expectations and the reality that has been generated by a brand or product. Brand performance measurement can be measured based on benchmarks such as customer loyalty to the brand/product, customer's desire to repurchase and recommend products based on their positive experiences with others. Brand performance is associated with the brand's outcome measures against the goals that have been set initially (Razak, Hidayat, Launtu, Putra, \& Bahasoan, 2020). Brand Performance reflects the strategic achievements of the brand and its success in the 
marketplace. The ability of a company's brand management in this sense is very important in achieving performance because it describes the ability to communicate important aspects to target customers (W. J. T. Lee et al., 2019). Food product SMEs must always survive in every competition. Food product SMEs measure brand performance based on benchmarks such as customer loyalty to the brand/product, customer desire to repurchase and recommend products based on their positive experiences with others.

Brand Management System is often associated with brand management that applies benchmarks of best brand management practices. Best brand management practices will always be discussed within the company's internal where the company applies brand evaluation procedures. The impact of brand management on company performance is a major concern for Brand Managers and Top Managers. Building and developing a brand with the concept of brand orientation, assessing the brand is the main goal(Dunes \& Pras, 2017).Brand management capabilities enable organizations to maximize branding activities, increase brand effectiveness in the market and develop long-term brand value (Iyer, Davari, Zolfagharian, et al., 2020; So, King, Hudson, \& Meng, 2017). The best brand management practice that can be carried out by food product SMEs is how to conduct internal company discussions where the company applies brand evaluation procedures. Market-oriented food product SMEs can lead to the development of various competitive strategies.

Market orientation is often the key to developing various market-based organizational capabilities that facilitate companies to use the information collected and distributed to develop competitive advantages (W. Liu \& Atuahene-Gima, 2018). Competitive strategy or brand positioning is often considered an organizational-level capability, because it includes various processes, activities, and strategies(Alshanty \& Emeagwali, 2019; Blankson et al., 2013) competitive advantage and business performance improvement(Falahat, Ramayah, Soto-Acosta, \& Lee, 2020; Tan \& Liu, 2014) Market-oriented food product SMEs can lead to the development of various competitive strategies, which ultimately lead to competitive advantage and improved business performance.

Internal branding is defined as a set of strategic processes that align and empower employees to provide appropriate customer experiences in a consistent manner and refers to the activities involved in aligning employees to the brand to create a symbolic relationship that can lead to a higher level of brand identification., (Ahmad, Iqbal, Kanwal, Javed, \& Javed, 2014) (Garas, Mahran, \& Mohamed, 2018) Central to the importance of internal branding is the perspective that human capital is one of the most important resources in an organization (Santos-Vijande, del Río-Lanza, Suárez-Álvarez, \& Díaz-Martín, 2013) .Another key factor that underscores the importance of internal branding is the idea that brand value is an explicit promise that employees need to fully understand and deliver consistently(Saleem \& Iglesias, 2016)). Internal Branding that can be done in SMEs for food products by targeting employees must focus on increasing capability and attitude performance to increase employee and customer interactions so as to create strong brand equity.

Based on several findings from the literature review, there are several gaps in the findings / inconsistencies of previous research results regarding the influence of the Brand Management System on Brand Performance. Research that supports the linkage of Brand Management System to Brand Performance (Dunes \& Pras, 2017; Likoum, Shamout, Harazneh, \& Abubakar, 2020; Santos-Vijande et al., 2013) which is indicated by positive and significant findings. Meanwhile research(Coleman, De Chernatony, \& Christodoulides, 2015); (Iyer, Davari, Zolfagharian, et al., 2020);(Iyer, Davari, Zolfagharian, \& Paswan, 2019) does not support the linkage of the Brand Management System to Brand Performance where it is shown that there is a negative influence and also some are not significant.

Service Dominant Logic is currently being used to study marketing communications and content about brands. The relationship between Service Dominant Logic and branding was also built early to provide a more holistic brand perspective as created by all company stakeholders (Stephen L. Vargo \& Lusch, 2017). Adopting the Service Dominat Logic theory(Stephen L. Vargo \& Lusch, 2017) about Value Resonance, this study synthesizes the concept of Value Resonance in Competitive Intensity as a consequence of sharing knowledge to improve Brand Performance. The purpose of this research is to develop a new theoretical model and empirical research model to fill the research gap regarding Brand Management System and Brand Performance. This gap can be filled by developing a new concept, namely Competitive Intensity Value Resonance. In addition to the Competitive Intensity Value Resonance concept, the Market Orientation concept, Internal Branding will also be studied because it is very relevant to the Competitive Intensity Value Resonance concept and is ultimately expected to increase Brand Performance in the food product industry. 


\section{Literature Review}

\section{Service Dominant Logic}

Service Dominant Logic is currently being used to study marketing communications and content about brands. The relationship between Service Dominant Logic and branding was also built early to provide a more holistic brand perspective as created by all company stakeholders(Robert F Lusch \& Vargo, 2014; Stephen L. Vargo \& Lusch, 2017).Branding that supports Service Dominant Logic focuses on the process of adding value, which results in shaping the customer experience. Thus this point of view presents brands with a broader role that interacts among all customers, companies, stakeholder networks and employees(Brodie, Löbler, \& Fehrer, 2019).Competition between companies in any field today will lead to service activities. The main concept in marketing that exports services as the main domain in competition is known as Service Dominant Logic. Service dominant logic theory is also based and consistent on core competency theory. In this view, key competencies, basic knowledge, and expertise are developed for economic entities that represent potential competitive advantages. The main competence is not a physical asset, but an intangible process.

The main competence is collective learning in organizations, especially how to coordinate various production skills and integrate them in various technology flows (Robert F. Lusch, Vargo, \& O'Brien, 2007). Identification of services in Service Dominant Logic, namely the application of resources for various activities, as an attribute of economic and non-economic exchange. Activities stem from specific knowledge and abilities that are carried out, in order to produce 'value' which is the purpose of exchange. The purpose of exchange is not the 'goods', but the value of a product, goods only as a transmission. In line with core competency theory, service dominant logic theory adopts the concept that core competencies can be values that will differentiate one organization from another. Companies or organizations create value, and that value is embedded in the company's products and services (Stephen L Vargo \& Lusch, 2008).

\section{Brand Management System and Competitive Intensity Value Resonance}

Brand support in the Brand Management System can ensure that the brand has an important role in the business model. The concept of internal branding in the Brand Management System is associated with the commitment of frontline employees to the brand and collaboration in ensuring the consistency of the brand experience (Coleman et al., 2015).Brand Management System needs a way to build strong relationships with customers, therefore companies really need development.(Santos-Vijande et al., 2013) Brand Management System is often associated with brand management that applies benchmarks of best brand management practices. Best brand management practices will always be discussed within the company's internal where the company applies brand evaluation procedures. The impact of brand management on company performance is a major concern for Brand Managers and Top Managers.

Building and developing a brand with the concept of brand orientation, assessing the brand is the main goal (Dunes \& Pras, 2017). An efficient Brand Management System makes it possible to achieve a competitive advantage by creating and maintaining a strong brand. When competition in the market is intense, product development becomes important to gain market advantage (Iyer, Davari, Srivastava, \& Paswan, 2020).From a managerial perspective, organizations provide insights to facilitate the brand management process in an organization. In particular, to develop brand management capabilities, organizations can benefit from processes that seek to meet customer needs through exploratory and proactive information seeking, and at the same time, pursue processes that focus on capturing existing customers and competitor trends in the market.(Iyer et al., 2019).

Previous research (Likoum et al., 2020) describes how a strong brand management system (BMS) instrument stimulates the achievement of competitive advantage over competitors. The relatively high level of Brand Management System activity increases the intensity of competition. Therefore the following hypothesis is proposed:

H1: Brand Management System positively influences Competitive Intensity Value Resonance

\section{Market Orientation and Competitive Intensity Value Resonance}

Market-oriented behavior can lead to the development of various competitive strategies, which ultimately leads to competitive advantage and increased business performance (Tan \& Liu, 2014) When a company pursues a proactive market orientation, it will seek to identify and respond to unmet customer needs in the market(W. Liu \& Atuahene-Gima, 2018).To identify unmet needs, companies will need a market-driven exploratory learning mindset.

Therefore, the company is likely to use a positioning strategy that is in accordance with the company's mindset and related competencies (Blankson et al., 2013) Competitive strategy or brand positioning is often 
considered an organizational-level capability, because it includes a variety of processes, activities in echoing the value of competition intensity and market-focused resource strategy, such as market orientation, influence strategy selection and implementation, which ultimately leads to market positioning and performance. companies (Iyer, Davari, Srivastava, et al., 2020).

Market orientation is often the key to developing various market-based organizational capabilities that facilitate companies to use the information collected and distributed to develop competitive advantages, in this case there is a relationship between market orientation and competitive intensity value resonance. (Iyer et al., 2019)

H2: Market Orientation positively influences Competitive Intensity Value Resonance

\section{Market Orientation and Internal Branding}

Market orientation seeks to understand and take advantage of the factors surrounding the company. Companies are able to identify and respond to customer needs and provide products and services that match those needs, so market orientation is a key instrument in developing a sustainable competitive advantage (Gupta, Gallear, Rudd, \& Foroudi, 2020).(Y.-K. Lee, Kim, Seo, \& Hight, 2015).Companies must first identify the various needs of market participants such as competitors, consumers, suppliers, and learn how to respond effectively to market changes. Creating products and services that will provide a competitive advantage(Santos-Vijande et al., 2013). Market orientation was initially conceptualized as a reactive approach where customer orientation is very much in line with the brand image, because customer needs are considered important. In addition, brand managers focus on creating value propositions based on customer mindsets and perceptions, leading to higher brand performance(Iyer et al., 2019)

From a corporate perspective, it enables companies to increase absorption capacity through reducing problems associated with identifying and addressing customer needs and transaction costs, thereby increasing the profitability of the market(Iyer, Davari, Srivastava, et al., 2020).The Market Orientation role mainly focuses on Internal Branding in terms of the idea of brand identity and consistency. Internal branding activities are often driven by market orientation which is expected to meet customer needs while maintaining the brand's core identity(Saleem \& Iglesias, 2016).

Market Orientation understands the potential effects and supports development on internal branding. Market Orientation has an influence on Internal Branding in the company, namely targeting employees to focus on increasing capability and attitude performance to increase employee and customer interactions and create strong brand equity (Hasni, Salo, Naeem, \& Abbasi, 2018). Therefore the following hypothesis is proposed:

\section{H3: Market Orientation positively influences Internal Branding}

\section{Competitive Intensity Value Resonance and Brand Performance}

Competitive Intensity refers to the level of market competition faced by the company and the level of competitive intensity. In such a situation, the company developing brand performance becomes important to gain market advantage. As competition in the product market increases, managing product development has become important in industrial marketing management(Martin \& Javalgi, 2016). To improve the performance of a successful brand, companies must have the necessary resources and skills to carry out initiatives on products. Thus, companies must design processing mechanisms and integrate the necessary resource skills for product innovation(Cowan \& Guzman, 2020). Competitive intensity plays an important role for the analysis of the relationship between competitive intensity and brand performance. All these perspectives reinforce the need to investigate the influence of competitive intensity and brand performance (W. Liu \& Atuahene-Gima, 2018). Brand Performance reflects the strategic achievements of the brand and its success in the marketplace. The ability of a company's brand management in this sense is very important in achieving performance because it describes the ability to communicate important aspects to target customers (W. J. T. Lee et al., 2019).Brand performance measurement can be measured based on benchmarks such as customer loyalty to the brand/product, customers' desire to repurchase and recommend products based on their positive experiences with others (Iyer, Davari, Zolfagharian, et al., 2020). Brand performance is associated with brand outcome measures against the goals that have been set initially (Razak et al., 2020).

Brand Performance as a measure that refers to the success of a brand in the market which is measured in terms of brand image, brand awareness, customer brand loyalty and brand reputation. Brand awareness refers to the possibility that the brand name will appear in the minds of customers (Muhonen et al., 2017).Brand Performance reflects the strategic achievements of the brand and its success in the marketplace. The ability of a company's brand management in this sense is very important in achieving 
performance because it describes the ability to communicate important aspects to target customers(W. J. T. Lee et al., 2019).

In a managerial perspective, specifically to develop brand management capabilities, organizations can benefit from processes to meet customer needs through exploratory and proactive information seeking, and at the same time, processes that focus on existing customers and competitor trends in the market (Hoskins \& Griffin, 2019).Research (Tsai \& Hsu, 2014) shows that increasing competition intensity and market dynamism can result in increased brand performance. Competitive intensity plays an important role related to brand performance. Therefore the following hypothesis is proposed:

H4: Competitive Intensity Value Resonance positively influences Brand Performance

\section{Internal Branding and Brand Performance}

Internal Branding is defined as a set of strategic processes that align and empower employees to deliver a customized customer experience in a consistent manner. Another key factor that underscores the importance of internal branding is the idea that brand value is an explicit promise that needs to be fully understood and consistently delivered by employees (Ahmad et al., 2014). Various activities such as workshops, training sessions and communication programs can be developed and implemented in organizations to create employee and brand relationships. Internal Branding has been discussed to contribute to the success of brands within the company in various ways (G. Liu, Ko, \& Chapleo, 2017; Santos-Vijande et al., 2013).The concept of internal branding has been developed to help promote the company's brand to employees. The term is used to refer to the company's efforts to treat employees as internal customers, and to help them embrace the company's values. This gives rise to a shared understanding of a brand that provides employees with guidance and direction to deliver appropriate brand messages and customer experiences in a uniform manner (Iyer et al., 2019). Therefore, internal branding is expected to provide a work model that employees prefer and a clear direction to convey the meaning and value of the brand effectively (Iyer, Davari, Srivastava, et al., 2020).

Internal Branding involves communicating and educating employees about brand values, to increase intellectual and emotional engagement with the brand. Effective and consistent communication and training that reflects the brand message can be achieved. Internal Branding refers to a scheme that aligns employee awareness, observations and capabilities with company goals(Saleem \& Iglesias, 2016).The premise of internal branding involves communicating and educating employees about brand values, to increase their intellectual and emotional engagement with the brand. Effective and consistent communication and training reflects the brand message can achieve the following: First, enable employees to acquire brand knowledge, and understand brand insights. Second, increase the psychological contract between the company and individual employees. Third, encourage employee internalization of brand values. While brand knowledge allows employees to understand the brand and desired work behavior, psychological contract fulfillment inspires employees to internalize and run the brand to improve Brand Performance (Dechawatanapaisal, 2018).

Internal branding aims to convince employees that the company is a good place to work where they can commit and involve themselves towards the company's goals, namely to improve Brand Performance (Piehler, Grace, \& Burmann, 2018). Internal Branding is seen as a facilitator for brand orientation and strategic brand management processes, which ultimately have an impact on brand performance(Iyer, Davari, \& Paswan, 2018). Therefore the following hypothesis is proposed:

H5: Internal Branding positively influences Brand Performance 


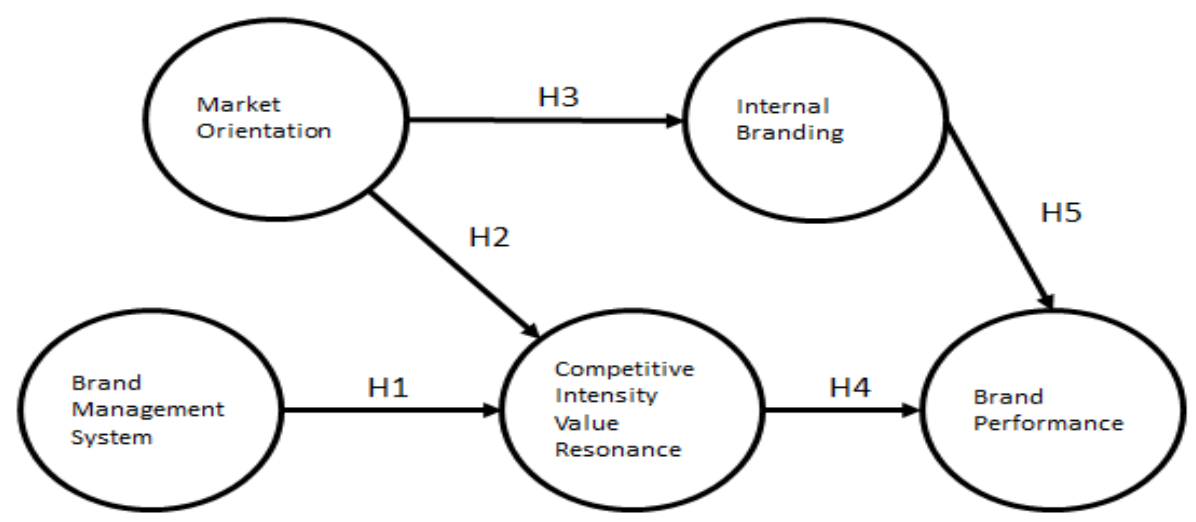

Figure 1. Research Model

(Source: Developed from various literatures for this research, 2021)

\section{Research Methods}

Primary data directly obtained from respondents through a questionnaire. The list of questions is arranged based on variables by providing answers. Then the questionnaire will be distributed to the selected respondents. The secondary data for this study is data on SMEs in food products and the unit of analysis of the study is business owners, managers, owners and managers of SMEs in food products in Central Java. The population in this study are business owners, managers, owners and managers at SMEs in Central Java. which is engaged in food products.

This study uses Structural Equation Modeling (SEM) with AMOS 24 as an analytical tool, so the determination of the sample must be fulfilled in the modeling, which is at least five times the number of parameters to 10 times (Ghozali, 2011). The total number of indicators in this study is 16 , so $16 \times 10=160$ so that the minimum number of samples that must be met in order to meet the assumption of sample adequacy is 160 samples. Purposive sampling method is applied in this study, the method of sampling technique where the researcher has certain criteria or goals on the object of research. The criteria used are SMEs that produce their own food products. Purposive sampling method was used to obtain accurate information from research subjects, namely business owners, managers, owners and managers of SMEs in Central Java which operates in the food products sector. Brand Management System is brand management that applies benchmarks of best brand management practices. Best brand management practices will always be discussed within the company's internal where the company applies brand evaluation procedures. Building and developing a brand with the concept of brand orientation, assessing the brand is the main goal(Dunes \& Pras, 2017).

Brand Management System indicators are: implementing the best brand management discussed in the company, implementing brand values during the training process for employees, increasing employee involvement in brand values (Dunes \& Pras, 2017). Market orientation is the process of generating and disseminating market intelligence to create and offer better value to customers. Market orientation seeks to understand and take advantage of the factors surrounding the company. The company is able to identify and respond to customer needs and provide products and services that suit those needs, so market orientation is the main instrument in developing a sustainable competitive advantage. (Y.-K. Lee et al., 2015)((Iyer et al., 2019; Iyer, Davari, Zolfagharian, et al., 2020).

Market Orientation indicators are: understanding customer demand for products, quickly responding to changes in product preferences, creating solutions for customer needs, all members in the company sharing important information about competitors ((W. J. Lee, 2015) (Iyer et al., 2019; Iyer, Davari, Zolfagharian, et al., 2020).

Internal Branding is defined as a set of strategic processes that align and empower employees to deliver a customized customer experience in a consistent manner. Another key factor that underscores the importance of internal branding is the idea that brand value is an explicit promise that employees need to fully understand and deliver consistently (Ahmad et al., 2014) (Iyer, Davari, Srivastava, et al., 2020). 
Internal Branding indicators are: employees attend training on brand values, employees periodically receive information about the brand, employees periodically receive information about brand management (Iyer, Davari, Srivastava, et al., 2020).

Competitive Intensity Value Resonance is echoing the value to face the intensity of competition that represents the magnitude of competitiveness between companies, which is characterized by fierce competition, the number of strong competitors, limited opportunities, as well as competition in advertising, promotions, prices, products, and services.(Iyer, Davari, Srivastava, et al., 2020; Likoum et al., 2020).Indicators of Competitive Intensity Value Resonance: companies are always alert to promotion wars, companies are always ready to face price competition, companies are always sensitive to new competitive moves almost every day(Iyer, Davari, Srivastava, et al., 2020) (Likoum et al., 2020).

Brand Performance reflects the strategic achievements of the brand and its success in the marketplace. The ability of a company's brand management in this sense is very important in achieving performance because it describes the ability to communicate important aspects to target customers (W. J. T. Lee et al., 2019) (Gammoh, Mallin, \& Pullins, 2020). Brand Performance indicators are: Our brand (company) is seen as having a higher quality. Our brand (company) is able to maintain prices according to quality Our brand (company) has a higher level of brand loyalty (Gammoh et al., 2020).

This research questionnaire is also equipped with closed and open questions aimed at obtaining complete information. Closed questions were made using a scale of 1-10, where a scale of 1 was given a score of strongly disagree and a score of 10 for strongly agree. Validity test is carried out to determine the level of ability of an instrument or data collection tool in revealing something that is the main target of the measurements carried out. Reliability testing is carried out to ensure the consistency of the measurement results of a variable or set of variables being measured (Ghozali, 2011).

\section{Results and Discussion}

The questionnaire that was distributed had questions regarding the demographic data of the respondents related to gender, age, education and position. The results of the complete demographic data of respondents are presented in Table 1, where from 160 respondents there are $111(69.37 \%)$ women and $49(30.63 \%)$ men. Researchers divided the age categories into 4 categories, namely from $<25$ years a number of 12 $(7.50 \%)$ respondents; age $25-40$ a total of $62(38.75 \%)$ respondents; age $41-55$ were $73(45.63 \%)$ respondents and over 55 years were $13(8.12 \%)$ respondents. The last education level of all respondents, namely elementary school as many as $8(5 \%)$ with a junior high education level of $10(6.25 \%)$, with a high school education level of $125(78.13 \%)$ with other education levels of $5(3.12 \%)$. Positions as business owners are $40(25 \%)$, Positions as managers are $18(11.25 \%)$, Positions as business owners and managers are $102(63.75 \%)$.

\begin{tabular}{lcc}
\multicolumn{2}{c}{ Table 1. Reliability Test and Variance Extract } & \\
\hline Variable & Reliability & Variance Extract \\
\hline Market Orientation ( MO) & 0,92 & 0,74 \\
Brand Management System ( BMS ) & 0,78 & 0,54 \\
& & \\
Internal Branding ( IB ) & 0,83 & 0,62 \\
Competitive Intensity Value Resonance(CIVR) & 0,90 & 0,75 \\
Brand Performance ( BP ) & 0,86 & 0,68 \\
\end{tabular}

Source: Primary data, processed, 2021

The reliability value $>0.70$ indicates that all reliable indicators are used as a measuring tool. The value of variance extract also exceeds the requirement that is $>0.50$. 


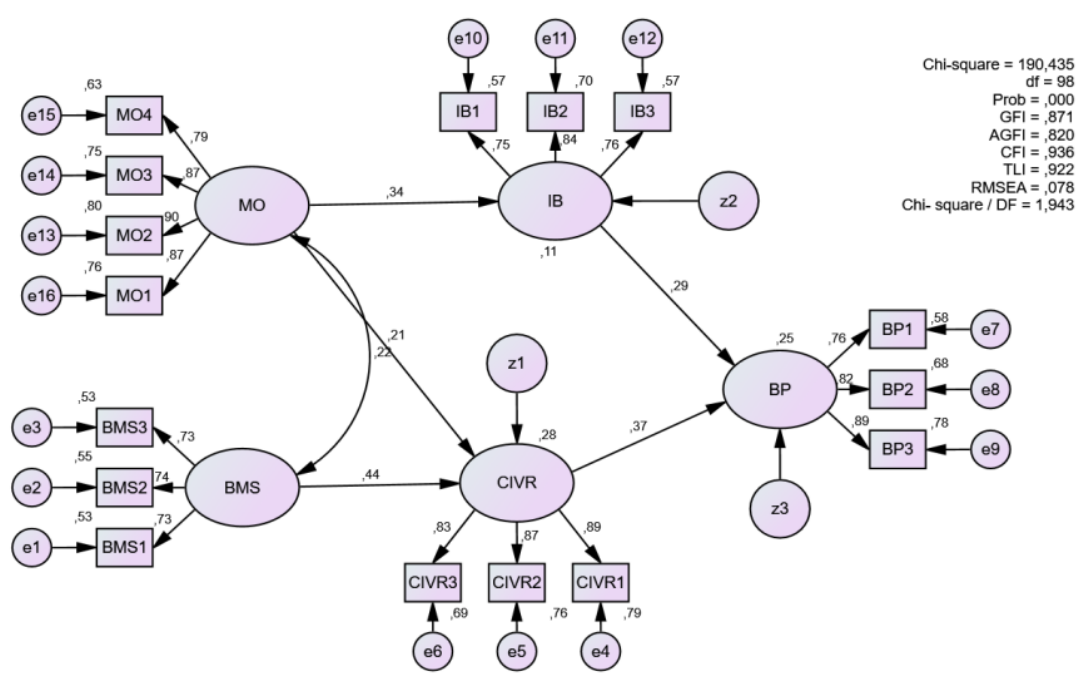

Figure 2. Full Test Structural Equation Modeling Before Modification ( Source: Primary data, processed, 2021)

From the test results, it can be seen that the probability value $<0.05$ indicates that the model does not fit the data. Therefore, it is necessary to modify the model.

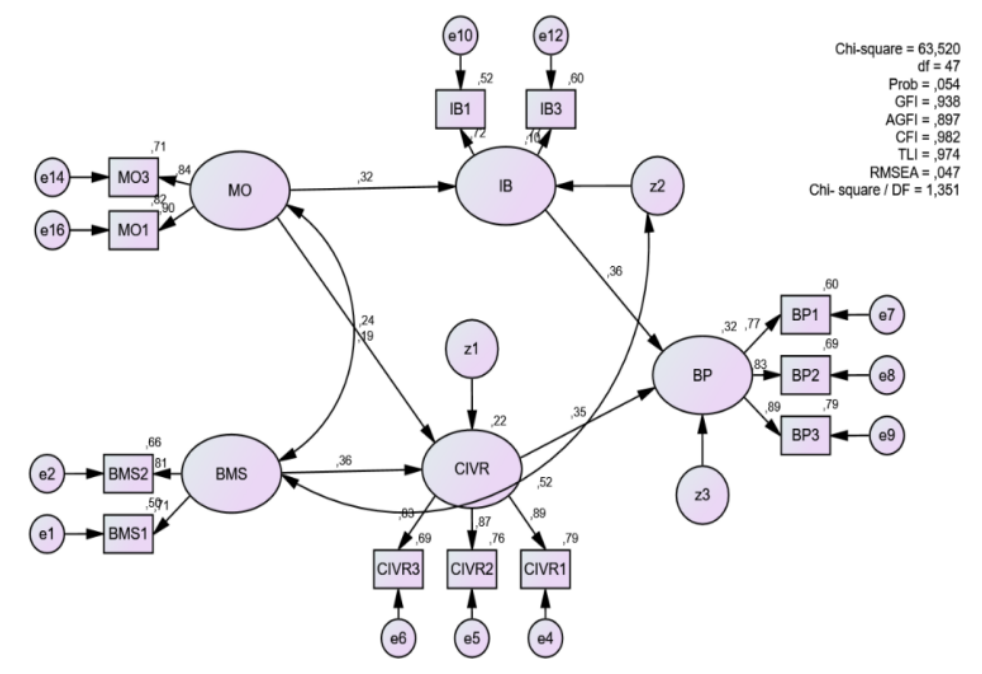

Figure 3. Full Test Structural Equation Modeling After Modification ( Source: Primary data, processed, 2021)

Modification of the model is done by removing the indicators and covariating the indicators based on the modification indices. The results show that all the fit model criteria are met. However, modification of the model requires theoretical justification. Especially the link between the Brand Management System and Internal Branding variables. 
Table 2. Hypothesis Testing

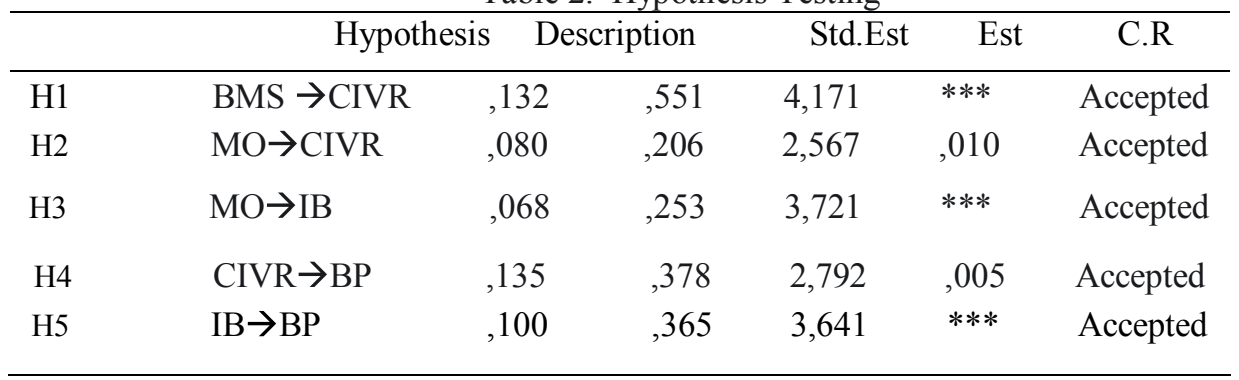

Source: Primary data, processed, 2021

\section{Conclusion and Implications}

The relatively high level of Brand Management System activity increases the intensity of competition. The results of this study indicate that the Brand Management System has a positive effect on Competitive Intensity Value Resonance. The results of this study support the results of previous research(Likoum et al., 2020) explaining how a strong brand management system instrument stimulates the achievement of competitive advantage over competitors. Competitive strategy or brand positioning is often considered an organizational-level capability, because it includes a variety of processes, activities in echoing the value of competition intensity and market-focused resource strategy, such as market orientation, influence strategy selection and implementation, which ultimately leads to market positioning and performance. companies(Iyer, Davari, Srivastava, et al., 2020).The results of this study indicate that Market Orientation has a positive effect on Competitive Intensity Value Resonance. The results of this study support the results of previous studies where market orientation is often the key to developing various market-based organizational capabilities that facilitate companies to use information collected and distributed to develop competitive advantages, especially on the intensity of competition(Iyer et al., 2019). The results of this study indicate that Market Orientation has an effect on Internal Branding. The results of this study support previous research where internal branding activities are often driven by market orientation which is expected to meet customer needs while maintaining the brand's core identity (Saleem \& Iglesias, 2016). The results of this study Market Orientation understand the potential effects and support the development of internal branding. Market Orientation has an influence on Internal Branding in the company, namely targeting employees to focus on increasing capability and attitude performance to increase employee and customer interactions and create strong brand equity (Hasni et al., 2018). The results of this study indicate that Competitive Intensity Value Resonance has a positive effect on Brand Performance. The results of this study support previous research which shows that increasing the intensity of competition can result in increased brand performance. Competitive intensity plays an important role related to brand performance. (Tsai \& Hsu, 2014). The results of this study indicate that Internal branding has a positive effect on Brand Performance. The results of this study support previous research that internal branding aims to convince employees that the company is a good place to work where they can commit and involve themselves towards the company's goal of increasing Brand Performance (Piehler et al., 2018). Internal Branding is seen as a facilitator for brand orientation and strategic brand management processes, which ultimately have an impact on brand performance (Iyer et al., 2018).

\section{Research Implication}

From a managerial perspective, organizations provide insights to facilitate the brand management process within an organization. In particular, to develop brand management capabilities, organizations can benefit from the process to meet customer needs through exploratory information search and develop brand management capabilities, organizations can benefit from processes to meet customer needs through exploratory and proactive information search. The results of this study provide two alternatives for managers and owners of small and medium businesses of food products in Central Java. First, the brand management system can be improved by implementing the best brand management discussed in food product SMEs. The best brand management practices will always be discussed within SMEs internally where SMEs apply brand evaluation procedures. Second, Brand Performance can be improved with higher quality. To improve the performance of a successful brand, companies must have the necessary resources and skills to carry out initiatives on products. Thus, companies must design processing mechanisms and integrate the necessary resource skills for food product innovation. 
Limitations and suggestions for furthers research

The limitation of this study is that the results of this study modify the model, this is done by removing indicators and covariating indicators based on modification indices. The results show that all the fit model criteria are met. However, modification of the model requires theoretical justification. Especially the link between the Brand Management System and Internal Branding variables. Therefore, further research is expected to add to the justification of the theory. Especially the link between the Brand Management System and Internal Branding variables. using a larger sample and adding dependent variables such as marketing performance, this needs to be investigated in future research because it is hoped that there will be further linkages between brand performance that support marketing performance.

\section{References}

Ahmad, N., Iqbal, N., Kanwal, R., Javed, H., \& Javed, K. (2014). The mediating role of employee engagement in relationship of internal branding and brand experience: Case of service organizations of Dera Ghazi Khan. International Journal of Information, Business and Management, 6(4), 26-41.

Alshanty, A. M., \& Emeagwali, O. L. (2019). Market-sensing capability, knowledge creation and innovation: The moderating role of entrepreneurial-orientation. Journal of Innovation \& Knowledge, 4(3), 171-178. Retrieved from https://www.sciencedirect.com/science/article/pii/S2444569X19300228. doi:https://doi.org/10.1016/j.jik.2019.02.002

Blankson, C., Cowan, K., Crawford, J., Kalafatis, S., Singh, J., \& Coffie, S. (2013). A review of the relationships and impact of market orientation and market positioning on organisational performance. Journal of Strategic Marketing, 21(6), 499-512.

Brodie, R. J., Löbler, H., \& Fehrer, J. A. (2019). Evolution of service-dominant logic: Towards a paradigm and metatheory of the market and value cocreation? Industrial Marketing Management, 79, 3-12. Retrieved from https://www.sciencedirect.com/science/article/pii/S001985011930207X. doi:https://doi.org/10.1016/j.indmarman.2019.03.003

Coleman, D. A., De Chernatony, L., \& Christodoulides, G. (2015). B2B service brand identity and brand performance. European Journal of Marketing.

Cowan, K., \& Guzman, F. (2020). How CSR reputation, sustainability signals, and country-of-origin sustainability reputation contribute to corporate brand performance: An exploratory study. Journal of Business Research, 117, 683-693. Retrieved from https://www.sciencedirect.com/science/article/pii/S0148296318305691. doi:https://doi.org/10.1016/j.jbusres.2018.11.017

Dechawatanapaisal, D. (2018). Employee retention: the effects of internal branding and brand attitudes in sales organizations. Personnel Review.

Dunes, M., \& Pras, B. (2017). The impact of the brand management system on performance across service and product-oriented activities. Journal of Product \& Brand Management.

Falahat, M., Ramayah, T., Soto-Acosta, P., \& Lee, Y.-Y. (2020). SMEs internationalization: The role of product innovation, market intelligence, pricing and marketing communication capabilities as drivers of SMEs' international performance. Technological Forecasting and Social Change, 152, 119908. Retrieved from http://www.sciencedirect.com/science/article/pii/S004016251931145X. doi:https://doi.org/10.1016/j.techfore.2020.119908

Gammoh, B. S., Mallin, M. L., \& Pullins, E. B. (2020). Dual foci of identification: the role of salesperson brand and organizational identification in driving brand performance. Journal of Product \& Brand Management.

Garas, S. R. R., Mahran, A. F. A., \& Mohamed, H. M. H. (2018). Internal corporate branding impact on employees' brand supporting behaviour. Journal of Product \& Brand Management.

Ghozali, I. (2011). Model Persamaan Struktural Konsep Aplikasi dengan Program AMOS 21.0. Semarang: Badan Penerbit Universitas Diponegoro

Gupta, S., Gallear, D., Rudd, J., \& Foroudi, P. (2020). The impact of brand value on brand competitiveness. Journal of Business Research, 112, 210-222. Retrieved from http://www.sciencedirect.com/science/article/pii/S0148296320301399. doi:https://doi.org/10.1016/j.jbusres.2020.02.033

Hasni, M. J. S., Salo, J., Naeem, H., \& Abbasi, K. S. (2018). Impact of internal branding on customer-based brand equity with mediating effect of organizational loyalty: An empirical evidence from retail sector. International Journal of Retail \& Distribution Management. 
Hoskins, J. D., \& Griffin, A. (2019). New product performance advantages for extending large, established fast moving consumer goods (FMCG) brands. Journal of Product \& Brand Management.

Iyer, P., Davari, A., \& Paswan, A. (2018). Determinants of brand performance: the role of internal branding. Journal of Brand Management, 25(3), 202-216.

Iyer, P., Davari, A., Srivastava, S., \& Paswan, A. K. (2020). Market orientation, brand management processes and brand performance. Journal of Product \& Brand Management.

Iyer, P., Davari, A., Zolfagharian, M., \& Paswan, A. (2019). Market orientation, positioning strategy and brand performance. Industrial Marketing Management, 81, 16-29. Retrieved from http://www.sciencedirect.com/science/article/pii/S0019850118303018. doi:https://doi.org/10.1016/j.indmarman.2018.11.004

Iyer, P., Davari, A., Zolfagharian, M., \& Paswan, A. (2020). Organizational ambidexterity, brand management capability and brand performance. Journal of Business \& Industrial Marketing.

Lee, W. J. (2015). Unpacking brand management superiority: examining the interplay among brand orientation and market-linking and controlling mechanisms. University of Tasmania,

Lee, W. J. T., O'Cass, A., \& Sok, P. (2019). How and when does the brand orientation-market orientation nexus matter? Journal of Business \& Industrial Marketing.

Lee, Y.-K., Kim, S.-H., Seo, M.-K., \& Hight, S. K. (2015). Market orientation and business performance: Evidence from franchising industry. International journal of hospitality management, 44, 28-37. Retrieved from https://www.sciencedirect.com/science/article/pii/S0278431914001480. doi:https://doi.org/10.1016/j.ijhm.2014.09.008

Likoum, S. W. B., Shamout, M. D., Harazneh, I., \& Abubakar, A. M. (2020). Market-sensing capability, innovativeness, brand management systems, market dynamism, competitive intensity, and performance: an integrative review. Journal of the Knowledge Economy, 11(2), 593-613.

Liu, G., Ko, W. W., \& Chapleo, C. (2017). Managing employee attention and internal branding. Journal of Business Research, 79, 1-11. Retrieved from http://www.sciencedirect.com/science/article/pii/S0148296317301753. doi:https://doi.org/10.1016/j.jbusres.2017.05.021

Liu, W., \& Atuahene-Gima, K. (2018). Enhancing product innovation performance in a dysfunctional competitive environment: The roles of competitive strategies and market-based assets. Industrial Marketing Management, 73, 7-20.

Lusch, R. F., \& Vargo, S. L. (2014). Service-dominant logic: Premises, perspectives, possibilities: Cambridge University Press.

Lusch, R. F., Vargo, S. L., \& O’Brien, M. (2007). Competing through service: Insights from servicedominant logic. Journal of Retailing, 83(1), 5-18. Retrieved from https://www.sciencedirect.com/science/article/pii/S0022435906000649. doi:https://doi.org/10.1016/j.jretai.2006.10.002

Luxton, S., Reid, M., \& Mavondo, F. (2017). IMC capability: antecedents and implications for brand performance. European Journal of Marketing.

Martin, S. L., \& Javalgi, R. R. G. (2016). Entrepreneurial orientation, marketing capabilities and performance: the moderating role of competitive intensity on Latin American International new ventures. Journal of Business Research, 69(6), 2040-2051.

Muhonen, T., Hirvonen, S., \& Laukkanen, T. (2017). SME brand identity: its components, and performance effects. Journal of Product \& Brand Management.

Piehler, R., Grace, D., \& Burmann, C. (2018). Internal brand management: introduction to the special issue and directions for future research. In: Springer.

Razak, M., Hidayat, M., Launtu, A., Putra, A. H. P. A. K., \& Bahasoan, S. (2020). Antecedents and consequence of brand management: empirical study of Apple's brand product. Journal of Asia Business Studies.

Saleem, F. Z., \& Iglesias, O. (2016). Mapping the domain of the fragmented field of internal branding. Journal of Product \& Brand Management.

Santos-Vijande, M. L., del Río-Lanza, A. B., Suárez-Álvarez, L., \& Díaz-Martín, A. M. (2013). The brand management system and service firm competitiveness. Journal of Business Research, 66(2), 148157. Retrieved from https://www.sciencedirect.com/science/article/pii/S0148296312002020. doi:https://doi.org/10.1016/j.jbusres.2012.07.007

So, K. K. F., King, C., Hudson, S., \& Meng, F. (2017). The missing link in building customer brand identification: The role of brand attractiveness. Tourism Management, 59, 640-651. Retrieved from 
http://www.sciencedirect.com/science/article/pii/S026151771630173X.

doi:https://doi.org/10.1016/j.tourman.2016.09.013

Tan, M., \& Liu, Z. (2014). Paths to success: An ambidexterity perspective on how responsive and proactive market orientations affect SMEs' business performance. Journal of Strategic Marketing, 22(5), 420441.

Tsai, K.-H., \& Hsu, T. T. (2014). Cross-Functional collaboration, competitive intensity, knowledge integration mechanisms, and new product performance: A mediated moderation model. Industrial Marketing Management, 43(2), 293-303.

Vargo, S. L., \& Lusch, R. F. (2008). Service-dominant logic: continuing the evolution. Journal of the Academy of Marketing Science, 36(1), 1-10.

Vargo, S. L., \& Lusch, R. F. (2017). Service-dominant logic 2025. International Journal of Research in Marketing, 34(1), 46-67. Retrieved from https://www.sciencedirect.com/science/article/pii/S0167811615302007. doi:https://doi.org/10.1016/j.ijresmar.2016.11.001 